\title{
Correction to: Oceanisphaera aquimarina sp. nov., Isolated from Oil-Contaminated Sediment of Ocean Coastal Area from South Korea
}

\author{
Seonghyeon $\mathrm{Cho}^{1} \cdot$ Sang-Seob Lee ${ }^{1}$
}

Published online: 27 November 2018

(c) Springer Science+Business Media, LLC, part of Springer Nature 2018

\section{Correction to: Curr Microbiol (2016) 73:618-623 https://doi.org/10.1007/s00284-016-1103-z}

The original version of this article unfortunately contained a mistake in the provided KEMB accession number.

The corrected version is given below:

On page 618, the text, "Oceanisphaera as Oceanisphaera aquimarina sp. nov. $\left(=\right.$ KEMB $\left.1002-058^{\mathrm{T}}=\mathrm{JCM} 30794^{\mathrm{T}}\right)$ " should read as "Oceanisphaera as Oceanisphaera aquimarina sp. nov. (= KEMB 2255-028 $\left.{ }^{\mathrm{T}}=\mathrm{JCM} 30794^{\mathrm{T}}\right)$ ", The GenBank/EMBL/DDBJ accession number for the 16S rRNA sequence of strain $\mathrm{S}_{3}{ }^{\mathrm{T}}\left(=\mathrm{KEMB} 2255-028^{\mathrm{T}}=\mathrm{JCM}\right.$ $30794^{\mathrm{T}}$ ) is KR003110.
The original article can be found online at https://doi.org/10.1007/ s00284-016-1103-z.

Sang-Seob Lee

sslee@kyonggi.ac.kr

1 Department of Biological Engineering, Kyonggi

University, 94-6 Iui-dong Yeongtong-gu, Suwon 443-760,

Republic of Korea
On page 622, the text, "The type strain, $\mathrm{S} 33^{\mathrm{T}}$ (= KEMB $\left.1002-058^{\mathrm{T}}=\mathrm{JCM} 30794\right)$, was isolated from an oil-contaminated sands of the Tae-an coastal area of South Korea" should read as "The type strain, $\mathrm{S} 33^{\mathrm{T}}$ (= KEMB 2255-028 ${ }^{\mathrm{T}}$ $=\mathrm{JCM} 30794^{\mathrm{T}}$ ), was isolated from an oil-contaminated sands of the Tae-an coastal area of South Korea". 